\title{
СТОМАТОЛОГІЧНI АСПЕКТИ
}

\author{
(C) D.S. Avetikov, O.P. Bukhanchenko, Aipert V.V., K.P. Lokes, I.V.
}

UDC $616.716 .616 .5-003.92-072$

DOI https://doi.org/10.31718/mep.2018.22.5-6.03

\section{ULTRASOUND STUDY OF PATIENTS WITH KELOID SCARS OF THE MAXILLOFACIAL AREA}

D.S. Avetikov, O.P. Bukhanchenko, Aipert V.V., K.P. Lokes, I.V.

Ukrainian Medical Stomatological Academy, Poltava.

The study is a part of scientific research work of Ukrainian Medical Stomatological Academy of the Ministry of Public Health of Ukraine: "Algorithm of surgical and conservative treatment of patients with cosmetic defects of the tissues of the maxillofacial area, involutional ptosis of the skin of the face and neck, pain facial syndromes, and the prevention of the formation of pathological scarring of tissues", state registration number 01100004629.

Незважаючи на можливості сучасної хірургії і дерматокосметології проблема диференційної діагностики пацієнтів 3 келоїдними рубцями залишається актуальною та достатньо значущою і в даний час. Як показує клінічна практика, принципове значення має не тільки сам факт і величина того чи іншого функціонального і естетичного дефекту при рубцевих змінах шкіри, але і ступінь їх негативного впливу на процес фізичної, психологічної та соціальної адаптації хворого. Метою нашого дослідження стало вдосконалити методи обстеження пацієнтів з келоїдними рубцями шкіри голови та шиї шляхом використання методів ультразвукової діагностики. Нами обстежено 50 пацієнтів з келоїдними рубцями голови та шиї. Поглиблене вивчення рубців проводилось за допомогою ультразвукового дослідження. Для порівняння використовували інтактну шкіру. Аналіз Уз - грам дозволив визначити кольорову ехологічну картину келоїдних рубців, яка значною мірою відрізнялась від дерми інтактної шкіри. Серед ехогенних ознак післяопераційних келоїдних рубців слід відзначити збільшення глибини залягання рубцевозміненої тканини у порівнянні з товщиною інтактної дерми у середньому на 8-11\%, зниження товщини епідермісу у середньому на 18-26\%, простежується чітка межа між інтактною шкірою та келоїдним рубцем, що є чіткою диференціальною ознакою даного типу рубця. Лише у 7\% випадків нами візуалізована межа з гіподермою у периферичних краях рубця, що свідчить про інфільтраційний характер росту келоїду та ще раз доводить його схожість із пухлиною. Сьогодні не існує універсального способу диференційної діагностики різних видів рубців шкіри голови та шиї, саме тому існує потреба в розробці інформативного та економічно доцільного методу діагностики. Ультразвукове дослідження рубців $\epsilon$ неінвазивним методом обстеження, за допомогою якого можливо об'єктивно, інформативно і безпечно оцінювати багаточисленні анатомічні структури, визначати тип та глибину залягання рубця.

Ключові слова: келоїдний рубець, ультразвукове обстеження, шкіра голови та шиї

Despite the possibility of modern surgery and dermatological cosmetology, the problem of differential diagnosis of patients with keloid scars remains relevant and significant at present. As clinical practice shows, not just the presents and the size of functional or aesthetic defect in scar tissue changes are important, but also the degree of their negative influence on the process of physical, psychological and social adaptation of the patient. The aim of our study was to optimize and improve the effectiveness of treatment of facial keloid scarring by identifying the type of scarred skin of the head and neck, and using ultrasound examination. The ultrasound method of investigation was performed on 50 patients with keloid scars of the head and neck. Clinical study of the general characteristics of the scar was supplemented by an additional analysis of the structural features of the cicatricial tissues by ultrasound examination. For the purpose of comparison, intact skin was used. Analysis of ultrasonography allowed to determine the color echogenic pattern of keloid scars, which differed substantially from the dermis of intact skin. Among the echogenic signs of postoperative keloid scarring, one should point out an increase in the depth of cicatrix of the tissue in comparison with the thickness of the intact derma, an average of 8-11\%, an average thickness of the epidermis is $18-26 \%$, a clear boundary between intact skin and keloid scar is traced, which is a clear differential sign of this type of scar. Only in $7 \%$ of cases, we have visualized the border with the hypodermis in the peripheral edges of the scar, which indicates the infiltration character of the growth of the keloid and again proves its similarity with the tumor. Today, there is no universal method for differential diagnosis of various types of scars of the head and neck. Therefore, it is necessary to develop an informative and economically expedient method of diagnostics. Ultrasonography of scarring is a non-invasive survey method that can objectively, informatively and safely evaluate numerous anatomical structures, determine the type and depth of scar formation.

Keywords: keloid scar, ultrasound study, the skin of head and neck.

* To cite this English version D.S. Avetikov, O.P. Bukhanchenko, Aipert V.V., K.P. Lokes, I.V. : Ultrasound study of patients with keloid scars of the maxillofacial area. . // Problemy ekologii ta medytsyny. - 2018. - Vol 22, № 5-6. - P. 14-18. 


\section{Introduction}

Rehabilitation of patients with scars of the maxillofacial area remains one of the most complex problems of surgical stomatology and maxillofacial surgery. Unfortunately, in recent years, the quantity of such patients has unceasingly increased. This is due to increased aesthetic demands of the society, as well as an increase in the number of cases of keloid scars formation, both after surgical interventions and involuntarily $[1,2]$.

The cicatricial tissues of the head and neck disrupt the psychoemotional state, form the feeling of hopelessness, inferiority, insecurity, reduce the spiritual and labor potential of the individual, often leading to the development of intercurrent diseases of psychosomatic origin such as neuroses, angina pectoris, hypertension and sometimes even a complete disability of the patient $[3,4,5]$. In addition, cicatricial skin deformities often lead to limitation of the temporomandibular joint mobility, both due to contractures, and as a result of damage to the tendons, which may also lead to characteristic anatomical changes [6].

In order to determine the condition of the scar tissue, plastic surgeons, in addition to the visual and tactile examination, use such instrumental research methods as radioisotope clearance, thermography, magnetic resonance imaging, capillaroscopy, and radiological examination $[7,8]$.

Several authors distinguish the following causes of the appearance of keloid scars: dysfunction of the endocrine system, general and local immunological disorders, autoantigens, lack of trace elements and ascorbic acid, tissue hypoxia and microcirculation disorders [9]. In some cases, the cause of pathological scar formation cannot be determined $[10,11]$. The keloid scar and the nearby skin were studied by electron-radioautographic method. On the basis of this study, it is possible to state that the keloid scar, as well as granulation tissue, consists of a separate microzone. It should be noted that externally unchanged skin, which is located near to keloid scar, is sharply different from the normal skin and the scar by a large number of cellular forms. Until now, there was no universal method for evaluation of all parameters of scar tissue. This fact prompted us to create an optimized approach for the treatment of pathological scars of the head and neck by determining a specific type of scar.

The development of ultrasound technology and the emergence of high-frequency sensors contributed to the introduction of ultrasound examination in dermatology, cosmetology, plastic and reconstructive surgery of the head and neck.

Ultrasound examination of keloid scars is a non-invasive method of investigation, which allows the evaluation of numerous anatomical structures objectively, informatively and safely, and determines the type and depth of the scarring tissue [12]. This method allows us to establish echogenic differences of keloid scars in comparison with intact skin with using of ultrasonic waves. During the analysis of quantitative data, it is possible to estimate the digital values of the echogenicity indices in different areas of keloid scars, as well as to establish divergence of quantities for their quantitative characteristics. The most perspective and current method is the comprehensive approach to the treatment of pathological scars according to the formation of a specific type of scar.

The aim of our study was to optimize and improve the effectiveness of treatment of facial keloid scarring by identifying the type of scarred skin of the head and neck, and using the ultrasound examination.

\section{Materials and methods}

The ultrasound method of investigation was performed on 50 patients with keloid scars of the head and neck; the time of scar tissue development ranged from 5 months to 1.5 years. Patients with keloid scars were under our supervision. Their type of scarred-wrapped tissue was confirmed not only clinically but also morphologically.

Clinical study of the general characteristics of the scar was supplemented by an additional analysis of the structural features of the cicarticial tissues by ultrasound examination with the Simens ACUSON CV 70 device (Siemens, Germany) with the frequency of the sensor 20-40 $\mathrm{MHz}$. At the same time, the thickness of keloid scars, the degree of differentiation, echogenicity, the feature of the architectonic layers of the skin, their homogeneity in the damaged area were evaluated. For the purpose of comparison, intact skin of 50 healthy people was used.

Patients under our supervision complained of the cosmetic defect due to the presence of scar in the face and neck. In addition, 32 patients also complained of pain of varying intensity, burning, itching, numbness, and a feeling of "running ants" in the area of scar tissue.

We applied ultrasound differentiation of the layered structure of keloid scars during the examination. We took into account the fact that the echolocation wave (frequency 21-25 Hz) may change the penetration rate depending on the density and elastic qualities of the epidermis tissues of the dermis and subcutaneous fatty tissue.

The change in the frequencies of ultrasonic waves allowed us to determine the rate of their spread, both in the intact skin and in the cicatrial tissues. The difference in the frequency of ultrasound was observed. Acoustic impedance was calculated in different layers of the skin and scarred tissues.

During the research, we used a pulsed ultrasonic wave reference system. We detected the difference between the wave-permeability indices, some of which passed through all layers of the dermis and partially reflected from each of its layers. Calculation of the time index between the beginning of pulse formation and its reflection from certain layers of the skin, the depth of the occurrence of keloid scars were performed.

For the purpose of mathematical substantiation and establishment of quantitative indicators of the echogenicity degree among the zones of ultrasound, we selected the following areas:

T1 - area of intact skin around the scar;

T2 - a part of the medial edge of the scar;

T3 - area of the lateral edge of the scar;

T4 - the middle area of the scar;

L1 - the boundary between the epidermis and the cicatrial tissue;

L2 - the border between the cicatrial tissue and the hypodermis;

L3 - the border between the medial edge of the scar and the intact derma;

L4 - the border between the lateral edge of the scar and the intact derma.

In order to objectivize the data, we introduced 2 coefficients:

L1 / 2 is an index that shows the nature of change in echogenicity indices in the central and peripheral tissues of the scar in its middle zone; 
L3 / 4 is an index that shows the nature of change in echogenicity in the medial and distal edges of the rumen.

Statistical data processing was performed using a simple variation series and the Mann Whitney method.

\section{Results and discussion}

At the initial stage of the research, we studied the echogenic structure of intact skin. In all cases, from the standpoint of echogenic qualities, the following layers can be distinguished:

- the upper layer, which is clearly limited to surface gel and epidermis, which has a conditionally homogeneous structure with the inclusions of "black particles";

- the middle layer, which is represented by derma limited from the upper boundary of the epidermis tissues, from below the layer of hypodermis;

- the lower layer, which is represented by the subcutaneous fatty tissue, which is limited by the mesh layer of the dermis from above. We did not study deeper layers.

Worthy of note is the fact that the top layer consists of two conventionally parallel strips, which are represented in the top with a dark, and light stripes below. The light strip described the echogenic structure of the epidermis and the ultrasound visualized homogeneous structural components throughout the region of the studied skin. This is an essential feature of the structure of the unchanging skin of the epidermis, which should be taken into account when comparing ultrasound scales by photos in similar studies in the epidermal layer of scar tissue.

The peculiarities of the data were regarding the rendering of the dermis layer: in terms of the proliferation of ultrasound waves, in $93 \%$ of cases it had a structure with reduced echogenicity. On scans, this layer had a fairly uniform structure, which according to the degree of "darkening" had somewhat higher rates than the upper layer of the epidermis. We have seen clear upper and lower bounds in which the upper limit was visualized by a more dense consistency, which is due to the morphology of dermal-epidermis bonds. The lower layer was visualized more fluffy, which is probably due to the presence of deep membranes that slip (with a fascio-fatty type of slip) with the interstitial of the elements of the fatty lobe of the epidermis [1] (Photo 1).

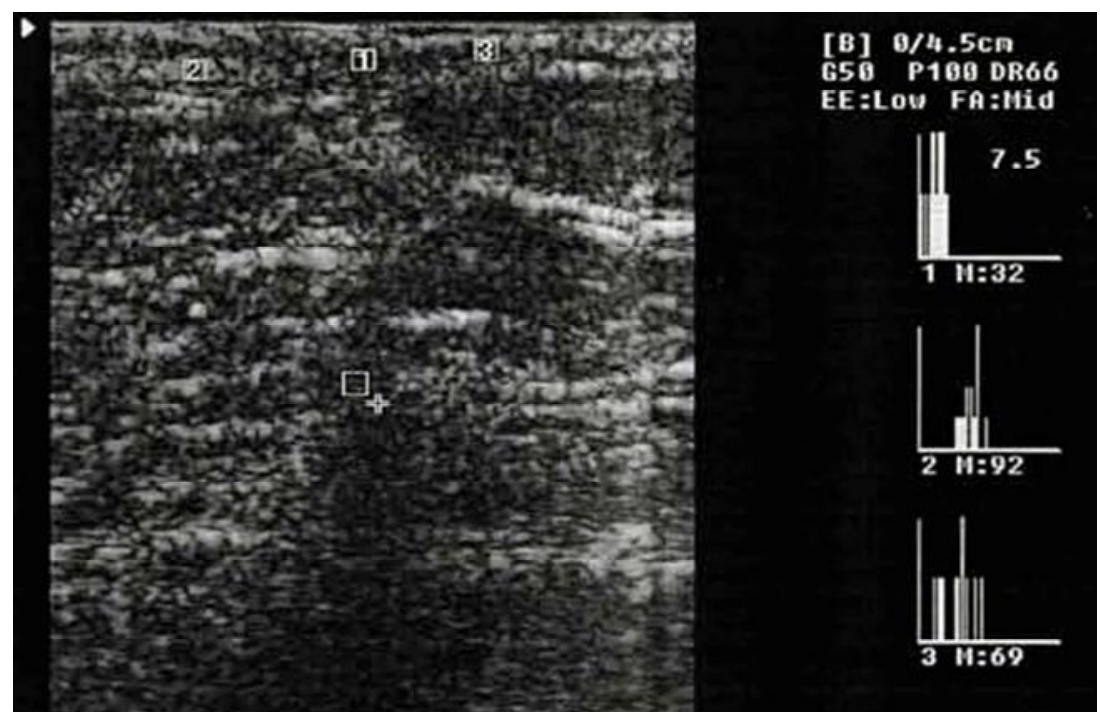

Photo 1. Ultrasound examination of intact skin.

1. - Superficial layer. 2. Middle layer 3. Deep layer

The lower layer, which is represented by subcutaneous fatty tissue with an upper boundary with a mesh layer of the dermis, had a reduced hyperergic structure in 98 cases. This layer had an inhomogeneous, loose structure in which there were areas with hypoechoic and hyperergic properties, the volume of such sites depended on the localization of the investigated objects:

- in the areas of slip (cheek, parotid, chewing, etc.), cells were found predominantly with hypoechoic properties in the ratio of $58 \%$ to $42 \%$;

- in areas of fixation (temporal, hollow areas, etc.) mainly areas with hyperergic properties (in 68\%) cases were visualized;

- in the intermediate zones, there was an almost dynamic correlation of the studied areas with respect to the echogenicity level: $52 \%$ were hypoechoic and $48 \%$ were hyperechogenic inclusions.

In patients with a keloid type of scar tissue, ultrasound imaging of the epidermis shows a decrease in its thickness by an average of $18-26 \%$. In our opinion, this is due to the reduction of the granular layer with hypoplasia of keratinocytes in the studded layer. In $72 \%$ of the studied keloid scars, it was possible to visualize the subepi- dermal region due to mucoid swelling of collagen fibers and smoothing of dermal papillae.

Significant changes were recorded in ultrasound investigations of intact derma compared with the keloid type of scar tissue. The depth of occurrence had rather varied values and reached the highest values from 4.8 to $13.1 \mathrm{~mm}$. Regarding the echogenicity of this zone, it should be noted that it is uneven in all areas in $62 \%$ of cases, we have recorded hypoechoic areas of irregular polygonal form, which in our opinion coincide with (the zones of growth of the keloid) and morphologically correspond to areas with high content of giant fibroblasts.

It is worth noting that during the entire spread of scar tissue, the boundary between them, intact skin and subordinate tissues is not observed, which is a clear differential sign of keloid scar and can be widely used in the creation of an algorithm for the treatment of patients with rubbing tissues.

It should be noted that only in $7 \%$ of cases we visualized the boundary with the hypodermis in the peripheral edges of the rumen, indicating the infiltration character of the growth of the keloid and once again proving its similarity to the tumor, this fact may be one of the important diagnostic criteria (Table 1). 
Table 1.

Distribution of the values indices in the echogenicity of keloid scars at ultrasound examination

\begin{tabular}{|c|c|c|c|c|c|c|c|c|c|c|}
\hline № & $\mathrm{T} 1$ & $\mathrm{~T} 2$ & $\mathrm{~T} 3$ & $\mathrm{~T} 4$ & $\mathrm{~L} 1$ & $\mathrm{~L} 2$ & $\mathrm{~L} 3$ & $\mathrm{~L} 4$ & $\mathrm{~L} 1 / 2$ & L3/4 \\
\hline 1 & 68 & 57 & 61 & 55 & 58 & 67 & 58 & 65 & 0.87 & 0.89 \\
\hline 2 & 64 & 52 & 58 & 49 & 53 & 69 & 54 & 61 & 0.77 & 0.88 \\
\hline 3 & 71 & 61 & 67 & 56 & 52 & 61 & 63 & 70 & 0.85 & 0.90 \\
\hline 4 & 62 & 51 & 59 & 46 & 45 & 72 & 55 & 62 & 0.62 & 0.88 \\
\hline 5 & 70 & 52 & 62 & 48 & 52 & 58 & 57 & 66 & 0.89 & 0.86 \\
\hline 6 & 58 & 49 & 53 & 44 & 46 & 56 & 52 & 57 & 0.82 & 0.91 \\
\hline 7 & 72 & 58 & 64 & 51 & 53 & 73 & 61 & 69 & 0.73 & 0.88 \\
\hline 8 & 67 & 56 & 61 & 49 & 45 & 64 & 59 & 64 & 0.70 & 0.92 \\
\hline 9 & 69 & 50 & 58 & 43 & 49 & 63 & 53 & 62 & 0.77 & 0.85 \\
\hline 10 & 61 & 46 & 56 & 41 & 43 & 59 & 49 & 60 & 0.73 & 0.81 \\
\hline 11 & 58 & 49 & 52 & 44 & 47 & 56 & 52 & 57 & 0.84 & 0.91 \\
\hline 12 & 71 & 58 & 53 & 52 & 49 & 64 & 63 & 59 & 0.77 & 1.06 \\
\hline 13 & 74 & 62 & 59 & 57 & 58 & 66 & 65 & 64 & 0.88 & 1.01 \\
\hline 14 & 66 & 49 & 61 & 53 & 52 & 62 & 53 & 66 & 0.84 & 0.80 \\
\hline 15 & 72 & 59 & 63 & 61 & 65 & 68 & 62 & 69 & 0.95 & 0.90 \\
\hline $\begin{array}{c}\text { Average } \\
\text { values }\end{array}$ & 66.8 & 53.9 & 59.1 & 49.9 & 51.1 & 63.8 & 57.1 & 63.4 & 0.81 & 0.89 \\
\hline
\end{tabular}

Analyzing the digital data, it should be noted that parameters of echogenicity of keloid scars display significant differences in the values, indicating the diversity of their clinical manifestations.

Attention is drawn to the fact that the average value of echogenicity index of intact skin around keloid scars was noted, at least the same as 66.8 (for women - 68.9 for men 63.2). This fact indicates a possible "infiltrative" type of cellulose rumen growth, which is confirmed by morphological studies [1].

As to echogenicity of the scar tissue in the periphery of the rumen, it should be noted that they were significantly lower in size and constituted 53.9 on the medial margin (in women - 55.4 in males - 49.7), and on the lateral edge - 59.1 ( for women - 61.9 for men - 56.1), respectively.

It should be noted that the smallest echogenicity index was recorded in the middle zone of the rumen and amounted to 49.9 (for women - 53.8 for men - 44.2), which indicates the largest tissue density of keloid scars.

The most controversial data was obtained in determining the values of echogenicity rates between scar tissue with epidermis and hypodermis: the difference in the rates was the minimum values and amounted to 51.1 (in women - 53.8 in men - 47.6) and 63.8 (in of women 65.2 for men - 59.8), respectively.

It should be noted that the discrepancies in the echogenicity of the tissues on the border between the intact derma and the medial and lateral edges of the keloid scar are obtained. It is important that this discrepancy was observed to be the largest and is 57.1 (for women 61.8, for men 53.2) and 63.4 (for women - 65.3, for men - 61.1) respectively. Obviously, this discrepancy is due to heterogeneity of connective tissue structures along the periphery, which in our opinion is an important feature in the primary diagnosis of keloid scars, especially in the early stages of their formation.

As to the research of $L 1 / 2, L 3 / 4$ indexes, the identity of digital data with their minimum differences $(0.81$ and 0.89 ), respectively, proved that the degree of echogenicity was reduced, both in the middle zone and in the peripheral tissues of the keloid scars, which in our opinion is a difference in the ultrasound examination and serves as an important diagnostic criterion.

An adequate approach to the methods of complex treatment of keloid scars of the head and neck skin is possible only taking into account the results of differential diagnosis and the determination of a specific type of scarred hemorrhagic skin (Photo 2).

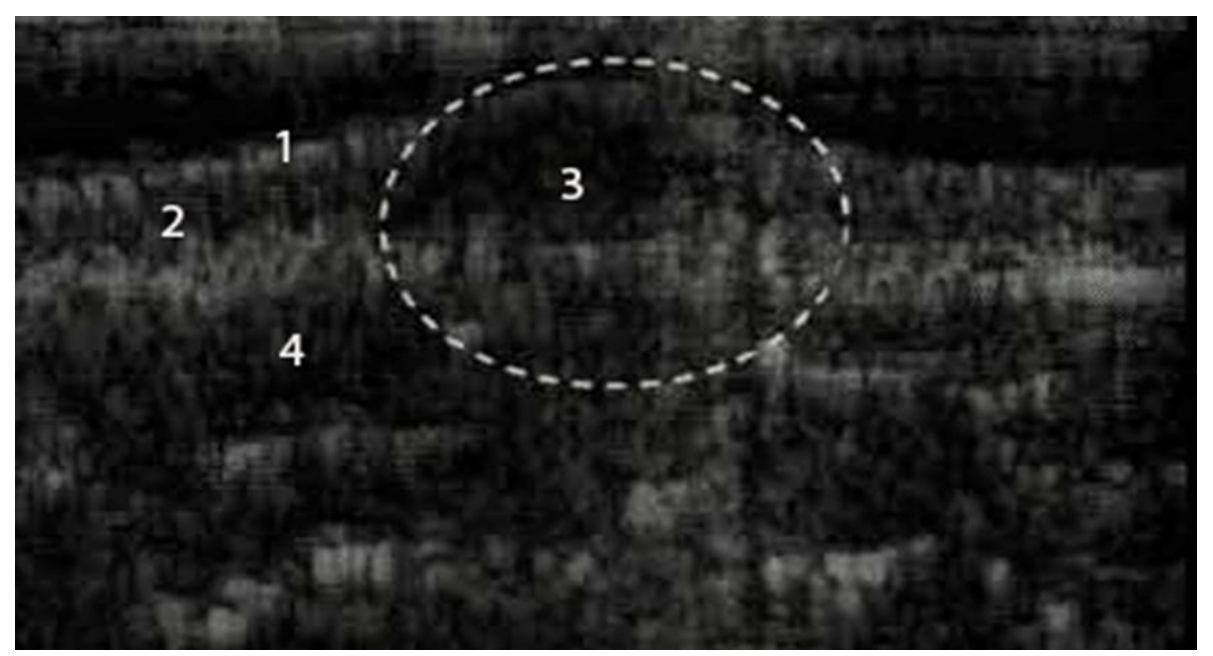

Photo 2. Ultrasound examination of keloid scar.

1. -Superficial layer 2. Middle layer 3. Deep layer 


\section{Conclusion}

In individuals with keloid scars, the actual area of the rumen is characterized by a pronounced thickening of the dermis, as well as unevenness of its thickness and echogenicity with the predominance of areas of reduced echodensity without a clear structural differentiation. Keloid scar is also characterized by the absence of clear boundaries between scar tissue and normal tissues. The digital characteristic of the variational series of echogenicity indicators obtained at certain points of the keloid scar may indicate a correlation between the scar density in different zones, the degree of its echogenicity at these points and its attribution with a certain type of scar. Ultrasound examination of maxillofacial scars is an effective method of non-invasive differential diagnosis of keloid scars, which allows us to evaluate the dynamics of changes in scar tissue.

Ultrasound study of keloid scars, as compared with intact skin, has its own geometric features, which allows us to attribute a scar to a certain group. This study enabled us to optimize and improve the methods of treatment of scarring of the face by means of determining the specific type of scarred-altered skin of the head and neck, using an ultrasound examination method.

The positive effects of the proposed method include its speed, accessibility, easiness in use and high reliability of the results.

A similar approach to the examination of patients with scarring of the maxillofacial area provides the optimal choice of the method of therapy and achieve maximum therapeutic effect.

\section{References}

1. Avetikov D.S. Kliniko-morfolohichne obgruntuvannya kompleksnoho likuvannya patolohichnykh rubtsiv, shcho lokalizovani $v$ dilyankakh holovy ta shyyi : monohrafiya / D.S. Avetikov, S.O. Stavyts'kyy. - Poltava, 2013. - $94 \mathrm{~s}$.

2. Sovremennyy podkhod $k$ khirurgicheskomu lecheniyu $i$ posleoperatsionnoy reabilitatsii patsiyentov $s$ zhabernymi kistami shei / S.N. Grigorov, L.R. Krinichko, S.A. Stavitskiy, Ye.P. Lokes // Parinskiye chteniya 2016. Obe- specheniye demograficheskoy bezopasnosti pri reshenii aktual'nykh voprosov khirurgicheskoy stomatologii i chelyustno-litsevoy khirurgii : sbornik trudov natsional'nogo kongressa s mezhdunarodnym uchastiyem. - Minsk, 2016. - S. 327-329.

3. Huang $\mathrm{C}$. The link between hypertension and pathological scarring: does hypertension cause or promote keloid and hypertrophic scar pathogenesis? / C. Huang, R. Ogawa // Wound Repair Regen. - 2014. - Vol. 22. - P. 462-466.

4. Ogawa R. Endothelial dysfunction may play a key role in keloid and hypertrophic scar pathogenesis - Keloids and hypertrophic scars may be vascular disorders / R. Ogawa, S. Akaishi // Med Hypotheses. - 2016. - Vol. 96. P. 51-60.

5. A novel regulatory function for mir-29a in keloid fibrogenesis / G.Y. Zhang, L.C. Wu, T. Liao [et al.] // Clin Exp Dermatol-2016. - Vol. 41. - P. 341-345.

6. Animal models of skin regeneration / B. GawronskaKozak, A. Grabowska, M. Kopcewicz, A. Kur // Reproductive Biology. - 2014. - Vol. 14. - P. 61-67.

7. Meshchyshen I. F. Metod vyznachennya okyslyuval'noyi modyfikatsiyi bilkiv plazmy krovi / I. F. Meshchyshen // Bukovyns'kyy medychnyy visnyk. - 1998. - T. 2, № 1. - S. 156-158.

8. Chevari S. Rol' superoksidreduktazy $\vee$ okislitel'nykh protsessakh kletki i metod opredeleniya yeye v biologicheskom materiale / S. Chevari, I. Chaba, Y. Sekey // Lab. delo. - 1985. - № 11. - S. 678-681.

9. Moffat J. A. Investigations into the role of sulfhydryl groups in the mechanism of action of the nitrates / J. A. Moffat, P. W. Armstrong, G. S. Marks // Canadian Journal of Physiology and Pharmacology. - 1982. - Vol. 60, № 10. - P. 1261-1266.

10. Fermentativnyy metod opredeleniya disbioza polosti rta dlya skrininga pro-i prebiotikov: metod. rekomendatsii / A.P. Levitskiy, O.A. Makarenko, I.A. Selivanskaya [i dr.] K.: GFTS MZU, 2007. - $22 \mathrm{~s}$.

11. Levitskiy A.P. Metody opredeleniya aktivnosti elastazy i yeye ingibitorov: metod. rekomendatsii / A.P. Levitskiy, A.V. Stefanov - K. : GFTS, 2002. - $15 \mathrm{~s}$.

12. Kamyshnikov V.S. Spravochnik po kliniko-biokhimicheskim issledovaniyam i laboratornoy diagnostike / V.S. Kamyshnikov. - M. : MEDpress-inform. - 2004. - 911 s.

Матеріал надійшов до редакції 03.12.2018 p. 